\title{
Cyclic dinucleotides (CDNs) anti-tumors response by activating DC and NK cell crosstalk
}

\author{
Juan $\mathrm{Fu}^{1 *}$, Drew Pardoll ${ }^{2}$, Young J Kim ${ }^{1,2}$ \\ From Society for Immunotherapy of Cancer 29th Annual Meeting \\ National Harbor, MD, USA. 6-9 November 2014
}

Intracellular bacterial, Listeria monocytogenes generates cyclic diadenosine monophosphate (c-di-AMP) can active interferon regulatory factor3 (IRF3) and nuclear factor kappa-light-chain-enhancer (NF- $\kappa \mathrm{B})$ and induces B cell and macrophage secretion of IFN- $\beta$ [1]. Cyclic diguanylic acid (c-di-GMP) also acts as an important signaling molecule in a variety of bacterial species infection functions. IFN- $\beta$ actives NK cells through Tyk ${ }_{2}$-STAT1 signal pathway. Our studied showed CDNs anti-tumor effective dependent IFN $\alpha / \beta$ receptors (IFNAR1/IFNAR2) on the cell plasma membrane. Some study showed c-di-GMP significantly inhibited the proliferation of human colon cancer cells in vitro [2]. Cyclic dinucleotides (CDNs, c-diAMP and c-di-GMP) are sensed by STING (stimulator of interferon genes). But CDNs were developed for prevent and therapeutic cancers, it was a novel method. We combined GM-CSF-producing tumor vaccine and TLR agonists enhanced systemic anti-tumor immunity. Our studied showed the regimen significantly inhibition mice tumors growth in B16 melanoma and colon cancer in vivo.
doi:10.1186/2051-1426-2-S3-P169

Cite this article as: Fu et al:: Cyclic dinucleotides (CDNs) anti-tumors response by activating DC and NK cell crosstalk. Journal for ImmunoTherapy of Cancer 2014 2(Suppl 3):P169.

\section{Authors' details \\ 'Department of Otolaryngology - Head \& Neck Surgery, Johns Hopkins University, School of Medicine, Baltimore, MD, USA. ²Department of Oncology and the Sidney Kimmel Comprehensive Cancer Center, Johns Hopkins University, School of Medicine, Baltimore, MD, USA.}

Published: 6 November 2014

\section{References}

1. Woodard JJoshua, lavarone Anthony T, Portnoy Daniel A: Science, Vol 328, 25 June, 2010. C-di-AMP secreted by intracellular Listeria monocytogenes activates a host type I interferon response.

2. Steinberger O, Lapidot Z, Ben-Ishai Z, Amikam D: Elevated expression of the CD4 receptor and cell cycle arrest are induced in Jurkat cells by treatment with the novel cyclic dinucleotide 3', 5'-cyclic diguanylic acid. FEBS Lett 444(1999):125-129.

'Department of Otolaryngology - Head \& Neck Surgery, Johns Hopkins University, School of Medicine, Baltimore, MD, USA

Full list of author information is available at the end of the article
Submit your next manuscript to BioMed Central and take full advantage of:

- Convenient online submission

- Thorough peer review

- No space constraints or color figure charges

- Immediate publication on acceptance

- Inclusion in PubMed, CAS, Scopus and Google Scholar

- Research which is freely available for redistribution
( Biomed Central 